Ann. Biol. anim. Bioch. Biophys., 1978, 18 (4), 863-869.

\title{
Pituitary response to LH-RH at different stages of gametogenesis in the rainbow trout (Salmo gairdneri)
}

\author{
par Claudine WEIL, R. BILLARD, B. BRETON, B. JALABERT \\ with the technical assistance of Pierrette REINAUD \\ Laboratoire de Physiologie des Poissons, I. N. R. A. \\ 78350 jouy en josas, France.
}

\begin{abstract}
Summary. Pituitary response to LH-RH has been studied in the male and female rainbow trout (Salmo gairdneri) at different stages of gametogenesis. The male was hardiy sensitive at the onset of spermatogenesis, but a response occured at the spermatid stage and continued during spermatogenesis and spermiation. We particularly studied the end of the female cycle. Response was low in immature fishes and in the early stages of oocyte maturation, but became stronger at vitelline maturation. The relationships of these responses to plasma and pituitary t-GTH levels are discussed.
\end{abstract}

\section{Introduction.}

Hypothalamic control of gonad activity (Peter, 1970), and especially of gonadotropin secretion in vitro (Breton et al., 1971b), has been demonstrated in teleost cyprinid fish. Synthetic LH-RH causes gonadotropin hormone release in vivo in the carp (Breton et Weil, 1973), trout (Crim and Cluett, 1974) and goldfish (Crim, Peter and Billard, 1976). However, the pituitary response in vivo to LH-RH differs, and depends on the time of the reproductive cycle in carp (Weil, Breton and Reinaud, 1975).

As it has been demonstrated that trout plasma gonadotropin levels vary in relation to the state of the gonads (Breton ef al., 1975 ; Crim, Watts and Evans, 1975), we wished to find out if pituitary response to $\mathrm{LH}-\mathrm{RH}$ varied with the stage of gameogenesis in the male and female trout. In the female, we have particularly studied the final stage of gamelogenesis.

\section{Material and methods.}

Trials were conducted in 1976 on adult 2-year old males during their second reproductive cycle. The animals came from the Etrun fish harm in the Pas-de-Calais department. They were kept in rearing tanks under natural photoperiod and tempe- 
rature until the experimental dates. The 4 lots studied corresponded to 4 different stages of gametogenesis according to the criteria of Billard and Escaffre (1975). The various stages were determined by microscopic examination.

Lot 1 , stage II : onset of gametogenesis ;

Lot 2, stage 111 : spermatocytes present and beginning of spermatid stage ;

Lot 3 , stage $V$ : all spermatogenetic stages present but no spermiation ;

Lot 4 , stages VI and VII : onset of spermiation.

Experiments were carried out on the females in February 1977 using fishes from Denmark. The animals were 2-years old and in their first reproductive cycle. Five lots were studied :

Lot 1 : immature animals (I) having oocytes of less than $100 \mu$ diameter ;

Lots 2-5 : animals presenting oocyles in different stages of maturation as defined by Jalabert ef al. (1976). The stage was determined after examination of several oocytes obtained by abdominal massage.

Lot 2, stages (i) and (o) : end of vitellogenesis (i) and oocyte with migrating germinal vesicle $(\mathrm{GV})$ (stage o) ;

Lot 3 , stage 1 : oocyte with peripheral GV;

Lot 4, stages 2 and 3 : maturing oocyte before GV breakdown (GVBD) (2) and after GVBD (3) ;

Lot 5 , stage 4 : mature and ovulated oocytes.

The animals of the different lots were anesthetized with $0.5 \mathrm{ml} / \mathrm{l}$ phenoxyethanol and then kept under anesthesia by perfusion $(0.3 \mathrm{ml} / \mathrm{l})$ in the gills during the experiment. $1 \mu \mathrm{g} / \mathrm{kg} \mathrm{LH}-\mathrm{RH}$ (Hoechst, Batch Op. R6) was injected into each experimental animal by intracardiac catheter; a buffer was injected by the same method into controls. Blood samples were taken with a heparinized syringe before (basic level) and 2, 4, 6, 8,15 and $20 \mathrm{~min}$. after the LH-RH or buffer injection. $t-G T H$ level in the samples was determined by radioimmunological assay (R|A) as previously described for c-GTH by Breton et al. (1971a). Antibody was raised against a pure t-GTH and used at a dilution of $1 / 2.10^{-5}$. The animals were killed $20 \mathrm{~min}$. later and the pituitary excised and ground to defermine t-GTH content by RIA. A piece of testis was fixed for quantitative analysis of germ cells.

LH-RH response was studied by characterizing the gonadotropin secretion of each fish by a single overall value, obtained by adding the t-GTH levels from 2 to min. after the basic level had been subtracted from each value. All fish having an overall value higher than that of the corresponding control lot were considered as responsive to $\mathrm{LH}-\mathrm{RH}$. We term this overall value « $\mathrm{t}-\mathrm{GTH}$ secretion during $20 \mathrm{~min}$. » in order to simplify.

Statistical methods. - Mean confidence intervals $(P<0.05)$ were computed only when there were more than 5 animals in a lot. Samples were compared either by variance analysis or by the U-test of Mann-Whitney (non-parametric method). 


\section{Results.}

Pituitary and plasma t-GTH levels (table 1).

Males. - Basic plasma t-GTH level was low at the onset of gametogenesis (stage II, lot 1) and increased when spermatocytes were present (stage III, lot $2: P<0.001$ ). It then remained constantly high until spermiation. Pituitary t-GTH level was low in the first stages (II and III, lots 1 and 2) and then increased to a maximum at spermiation (lot 4).

TABLE 1

Plasma (bosic level) and pituitary t-GTH levels

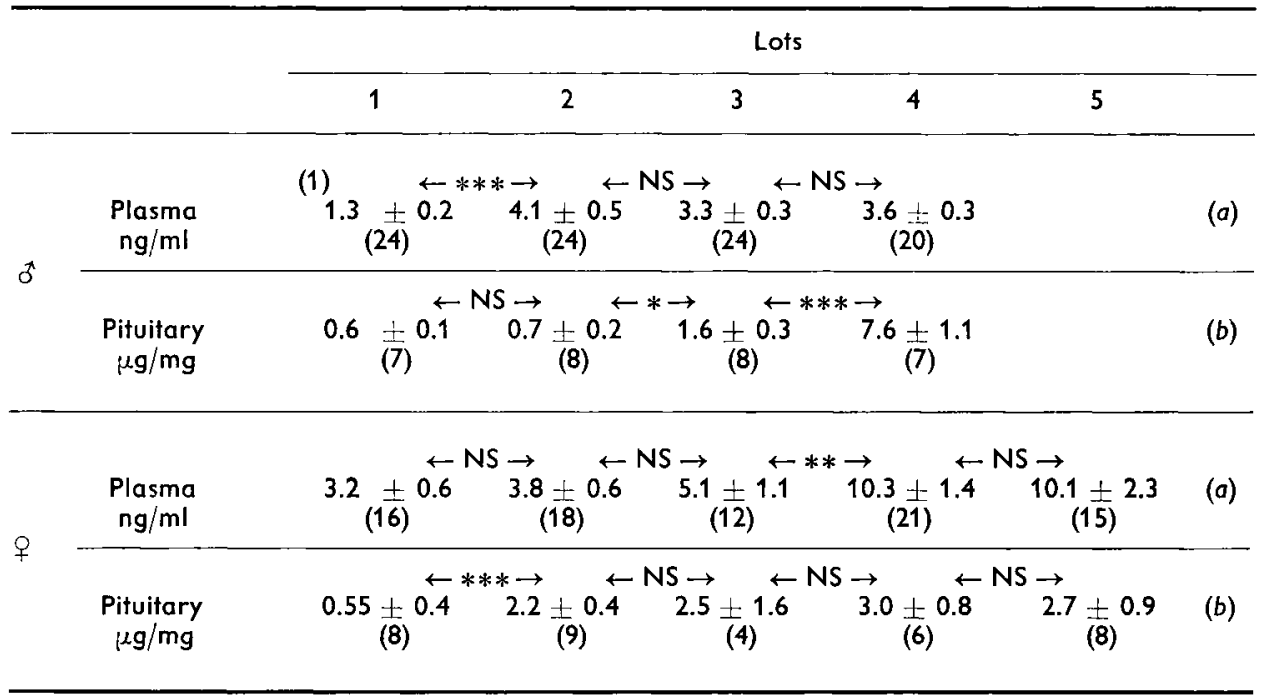

(1) : mean \pm s.e.

(a) : variance analysis.

(b) : Mann-Whitney U-test.

NS : $\mathrm{P}>0.05 ; *: \mathrm{P}<0.05 ; * *: \mathrm{P}<0.025 ; * * *: \mathrm{P}<0.001$.

( ) : Number of animals. The mean basic level of t-GTH was computed using data from control and experimental animals. Mean pituitary t-GTH content was computed from data on control animals.

Females. - Basic plasma t-GTH, level was low in immature fish and at the end of vitellogenesis (lots 1 and 2), but increased progressively during oocyte maturation. The lots 3 and 4 (« oocyte with peripheral GV » and « maturing oocyte ») showed a significant difference $(P<0.025)$. At ovulation (lot 5$)$, the level was still high. Pituitary t-GTH was constantly high in lots 2 to 5 (« end on vitellogenesis » until « ovulation ») as compared to immature fish (lot $1: P<0.001$ ).

LH-RH response.

Males (fig. 1a). - At onsel of gametogenesis (stage II), 1 animal out of 8 showed a very low response. LH-RH sensitivity increased when spermatocytes were present 
(stage III). At that stage, 2 animals out of 8 responded to LH-RH; one of these showed a very high peak $(90 \mathrm{ng} / \mathrm{ml})$. When all the spermatogenetic stages were present (stage V), 3 out of 4 animals responded as compared to the controls. However, maximum t-GTH was about $6 \mathrm{ng} / \mathrm{ml}$. At spermiation (stages VI and VII), 2 animals out of 5 showed sensitivity; high t-GTH values were found at that stage in some control subjects. Due to the heterogeneity of response in control and experimental animals beginning at stage III, a significant difference $(P<0.05)$ between the overall mean value of treated animals and controls only appeared at stage $V$.

Females (fig. $1 b$ ). - Because of the small number of animals studied, our results can only be considered as preliminary. Immature animals in the early stages of oocyte maturation showed a weak LH-RH response. Two out of 5 subjects responded at immature stage (I); 3 out of 5 at stages (i) and (o), and 1 out of 2 at stage (1). The maximum value found was $8 \mathrm{ng} / \mathrm{ml}$. Large amounts of t-GTH were only secreted at the matured oocyte stage (lots 2 and 3 ) ; 4 subjects out of 7 responded and 2 of them had t-GTH peaks of $25 \mathrm{ng} / \mathrm{ml}$ and $13 \mathrm{ng} / \mathrm{ml}$, respectively. On the other hand, there was no response at ovulation, and $\mathrm{LH}-\mathrm{RH}$ even seems to have a depressive effect on t-GTH level.

We only found a significant difference in the overall mean between control and experimental animals at the matured oocyte stage $(P<0.037)$ and the ovulated stage $(P<0.028)$.

\section{Discussion.}

Pituitary response to $\mathrm{LH}-\mathrm{RH}$ varies during gametogenesis; there is none in the early stages of gametogenesis, but it increases later. This confirms the results of Crim and Cluetf (1974) who found that LH-RH didnot release t-GTH in seasonally imma-

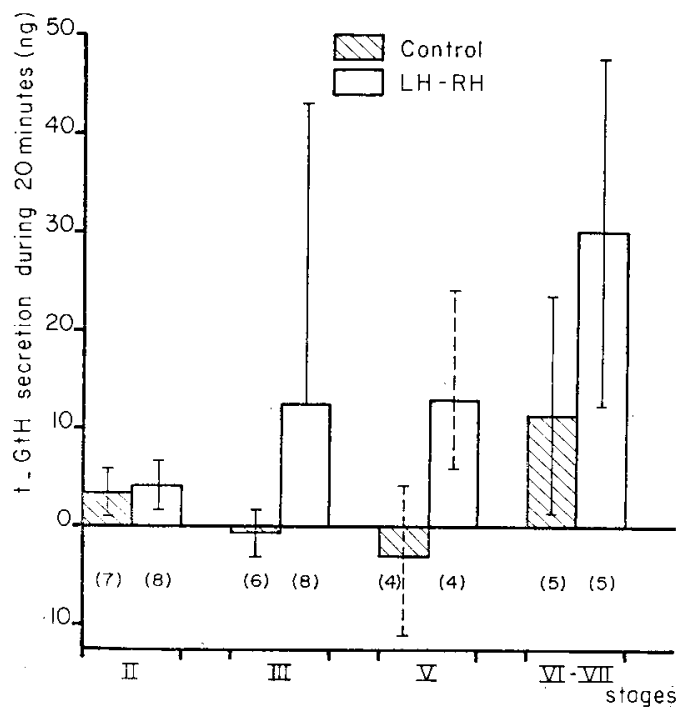

FIG. $1 a$. 


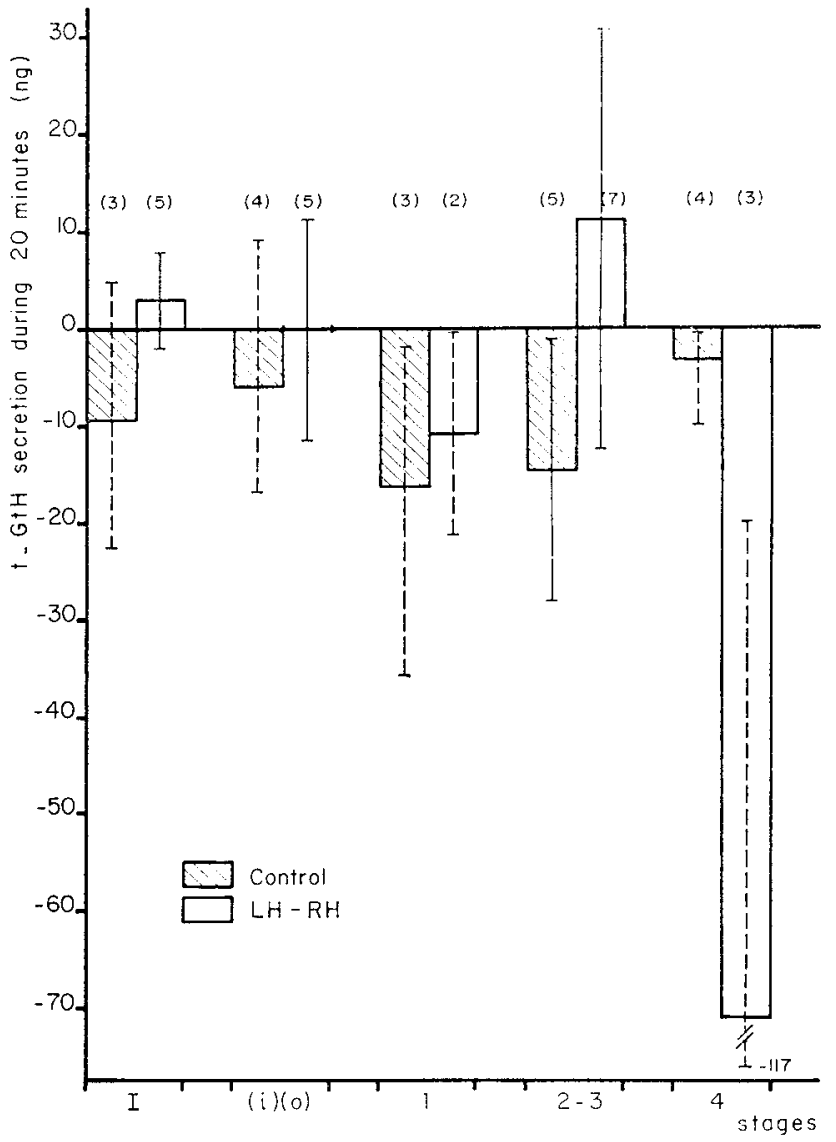

FIG. $1 b$.

FIG. $1 a$ and 1b. - Response to $L H-R H$ at differents stages of gametogenesis.

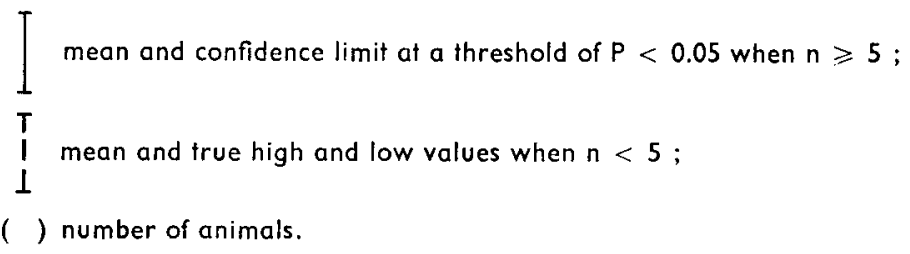

fure animals. The appearance at stage III of pituitary sensitivity to LH-RH corresponds to an increase of plasma t-GTH.

In females, basic level of plasma t-GTH increases progressively during oocyte maturation. It should be noted that pituitary response to $\mathrm{LH}-\mathrm{RH}$ varies in the same way until maturation when it is maximal. After ovulation, there is none. As pituitary t-GTH levels are identical from immature oocyte stages to ovulation, this difference in response may be due to the steroid environment. It is known now that estradiol $17 \beta$ level declines progressively until ovulation (Fostier ef al., 1978). Perhaps the ratio 
between estradiol $17 \beta$ and $17 \alpha$-hydroxy-20 $\beta$-dihydroprogesterone, the most potent steroid-inducer of trout oocyte maturation (Fostier, Jalabert and Terqui, 1973), modifies pituitary sensitivity to LH-RH.

After an LH-RH injection, the amounts of gonadotropin hormone released in trout plasma at reproductive time are low as compared to the carp (Weil et al., 1975). The maximum values observed vary between 30 and $100 \mathrm{ng} / \mathrm{ml}$ in carp, and between 6 and $25 \mathrm{ng} / \mathrm{ml}$ in trout. At that stage, pituitary gonadotropin hormone content is 15 times higher in the carp than in the trout female and 7 times higher than in the trout male. The only elevated level in trout was observed in a male in mid spermalogenesis (beginning of spermatids).

Symposium sur la Reproduction des Poissons Paimpont, France, 19-21 sepiembre 1977.

Acknowledgements. - We wish to thank Miss Aline Solari for her help in the statistical analysis. This work was partly supported by the CNRS, grant No 2104.

Résumé. La sensibilité hypophysaire au LH-RH a été étudiée chez la truite Arc-en-ciel mâle et femelle à différents stades de la gaméłogenèse. Chez le mâle, elle est presque nulle au début de la spermatogenèse ; elle apparaît lorsque le stade spermatide est atteint, puis se maintient au cours de la spermatogenèse et de la spermiation. Chez la femelle, la fin du cycle a été plus particulièrement étudiée. La réponse est faible chez les poissons immatures et aux premiers stades de la maturation ovocytaire; elle est la plus forte au moment de la maturation vitelline. Les relations de ces réponses avec les teneurs plasmatiques et hypophysaires en t-GTH sont discutées.

\section{References}

BILLARD R., ESCAFFRE A. M., 1975. Identification des stades de la spermatogenèse de la truite Fario d'après la morphologie des gonades et la spermiation. Bull. fr. Piscic., 253, 111-113.

BRETON B., KANN G., BURZAWA-GÉRARD E., 1971a. Dosage radioimmunologique d'une hormone gonadotrope de carpe (Cyprinus carpio L.). C. R. Acad. Sci. Paris, Sér. D, 272, 1515-1517.

BRETON B., JALABERT B., BILLARD R., WEIL C., 1971b. Stimulation in vitro de la libération d'hormone gonadotrope par un facteur hypothalamique chez la carpe Cyprinus carpio L. $C$. $R$. Acad. Sci. Paris, Sér. D, 273, 2591-2595.

BRETON B., WEIL C., 1973. Effets du LH-FSH-RH synthétique et d'extraits hypothalamiques de carpe sur la sécrétion d'hormone gonaciotrope in vivo chez la carpe Cyprinus carpio L. C. $R$. Acad. Sci. Paris, Sér. D, 277, 2061-2064.

BRETON B., JALABERT B., FOSTIER A., BILLARD R., 1975. Etude sur le cycle reproducteur de la truite Arc-en-ciel et de la tanche. J. Physiol., 70, 561-564.

CRIM L. W., CLUETT D. M., 1974. Elevation of plasma gonadotropin concentration in response to mammalian gonadotropin releasing hormone $(\mathrm{G}-\mathrm{RH})$ treatment of the male brown trout as determined by radioimmunoassay. Endocr. Res. Commun., 1, 101-110.

CRIM L. W., PETER R. E., BILLARD R., 1976. Stimulation of gonadotropin secretion by intraventricular injection of hypothalamic extracts in the goldfish Carassius auratus. Gen. comp. Endocr., 30, 77-82.

CRIM L. W., WATTS E. G., EVANS D. M., 1975. The plasma gonadotropin profile during sexual maturation in a variety of salmonid fishes. Gen. comp. Endocr., 27, 62-70.

FOSTIER A., JALABERT B., TERQUI M., 1973. Action prédominante d'un dérivé hydroxylé de la progestérone sur la maturation in vitro des ovocytes de la truite Arc-en-ciel Salmo Gairdneri. C. R. Acad. Sci. Paris, Sér. D, 277, 421-424. 
FOSTIER A., WEIL C., TERQUI M., BRETON B., JALABERT B., 1978. Plasma estradiol $17 \beta$ and gonadotropin during ovulation in rainbow trout (Salmo gairdneri R.). Ann. Biol. anim. Bioch. Biophys., 18, 929-936.

JALABERT B., BRY C., BRETON B., CAMPBELL C., 1976. Action de la 17 $\alpha$-hydroxy-20ß-dihydroprogestérone et de la progestérone sur la maturation et l'ovulation in vivo et sur le niveau d'hormone gonadofrope plasmatique t-GTH chez la truite Arc-en-ciel Salmo gairdneri. $C$. $R$. Acad. Sci. Paris, sér. D, 283, 1205-1208.

PETER R. E., 1970. Hypothalamic control of thyroid gland activity and gonadal activity in the goldfish, Carassius auratus. Gen. Comp. Endocr., 14, 334-356.

WEIL C., BRETON B., REINAUD P., 1975. Efude de la réponse hypophysaire à l'administration de Gn-RH exogène au cours du cycle reproducteur annuel chez la carpe Cyprinus carpio $L$. C. R. Acad. Sci. Paris, Sér. D. 280, 2469-2472. 